\title{
The future of work in automated warehouse from the perspective of the employees
}

\author{
Paulina Bałys \\ University of Economics in Katowice
}

Piotr Buła iD

Cracow University of Economics, University of Johannesburg

Dorota Dziedzic iD

Cracow University of Economics

Marta Uznańska iD

Cracow University of Economics

\section{Introduction}

Technological progress and automation have a tremendous impact on the way warehouse processes are carried out and managed. Elimination of errors, increased efficiency, significant reduction of operating costs, assurance of continuous availability of range of goods, improvement of process control, increased precision and speed of information flow are some of the benefits of introducing automation in the warehouse. Work conditions are changing, and work now requires the ability to use more advanced technical devices as well as cooperation with machines. Because the problem of human-machine interaction in warehouse work is not widely described in contemporary literature on the subject, the purpose of article is the attempt to assess the impact of automation on warehouse work. 


\section{Literature Review and Theoretical Framework}

\section{The concept of warehousing in today's economy in the literature}

Timely product or service delivery is one of the most important measures of a firm's quality. Therefore, the role and importance of the logistics system is of fundamental significance in the current climate. A well-organized logistic system that is adapted to today's challenges and requirements is not only an opportunity, but, in fact, essential. As the processes related to product or service delivery are increasing in complexity, and there is a need to adjust to the, more demanding, requirements of buyers, cost reduction is required to face competition in the markets Warehousing takes a central place in the logistic system. The warehouse is a place in the logistics system used for storing and distributing material goods ${ }^{1}$, as well as a functional and organizational unit intended for storing material goods (stocks) in separate storage buildings, which is equipped with appropriate devices and technical means of management and servicing by the human team ${ }^{2}$. The importance of warehouses in the modern economy is evidenced by numerical summaries developed by the Institute of Logistics and Warehousing 3 . Figure 1 presents the upward trend in commercial warehouse space in Poland over a seven-year period.

What is more, the first half of 2018 also showed good growth in the modern warehouse space market. The highest volume of lease transactions was recorded compared to the same period in previous years $\left(2.1\right.$ million $\left.\mathrm{m}^{2}\right)$, the lowest vacancy rate in history was registered (4\%), and the highest warehouse space under construction was achieved $\left(2.25 \text { million } \mathrm{m}^{2}\right)^{4}$. In 2018, Poland was the third most-chosen place in Europe to set up or move a warehouse, behind the Netherlands and Germany. In the first quarter of 2019, storage resources increased by another $623,000 \mathrm{~m}^{2}$, twice as much as in the corresponding period of $2018^{5}$. In addition to the dynamic development

1 D. Kisperska-Moroń, S. Krzyżaniak, Logistyka, Biblioteka Logistyka, Poznań 2009, p. 23.

2 M. Ferstsch, Stownik terminologii logistycznej, Instytut Logistyki i Magazynowania, Poznań 2016, p. 97.

3 The Institute of Logistics and Warehousing is a research institute within the meaning of the Act of 30 April 2010 on Research Institutes, registered in the District Court Poznań - Nowe Miasto and Wilda in Poznań, 8th Commercial Division of the National Court Register under KRS no. 0000052866.

4 J. Dobosiewicz, Padły trzy ważne rekordy na polskim rynku magazynowym, https://businessi nsider.com.pl/finanse/rynek-magazynowy-w-polsce-i-polrocze-2018-r/j94f2hx (accessed: 23.10.2019).

5 JLL, Rynek magazynowy w Polsce lipiec 2020, https://www.jll.pl/pl/trendy-i-analizy/badan ie/rynek-magazynowy-w-polsce (accessed: 27.10.2019). 
of the logistics sector as well as warehouse real estate market, labor market faces real problems in finding employees for warehouse work. Figure 2 illustrates the forecast for demand that employers have for warehousemen. In 2016, one can observe the balance between supply and demand prevailed, whereas in 2019 a deficit, in places large deficit, of jobseekers in this profession were clearly prevalent in Poland.

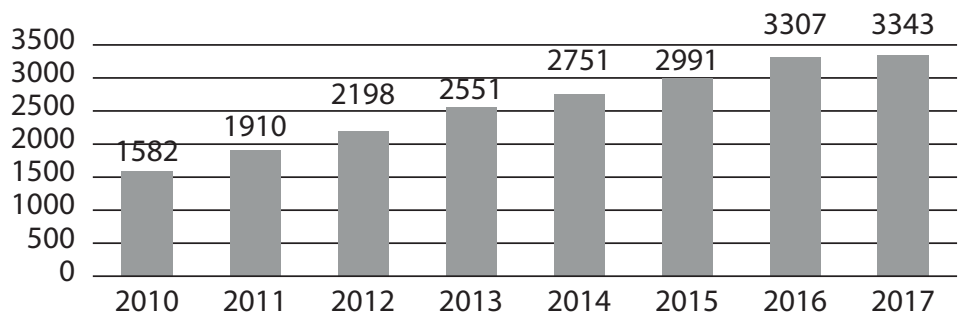

Figure 1. Commercial warehouse space in 2010-2017 in Poland

Source: own elaboration based on I. Fechner, G. Szyszka, Logistyka w Polce. Raport 2017, Biblioteka Logistyka, Poznań 2018, p. 106.
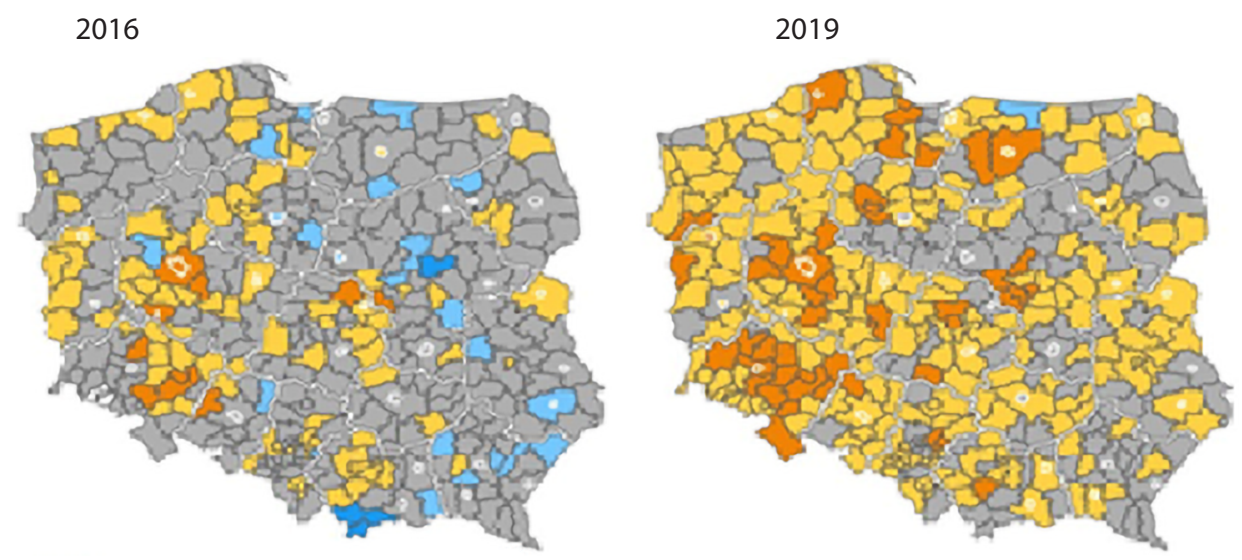

Large surplus of jobseekers

Surplus of jobseeker

Balance of demand and supply

Deficyt of jobseekers

Large deficyt of jobseekers

Figure 2. Relation between available employees and the needs of employers - warehousemen

Source: Barometr zawodów, https://barometrzawodow.pl (accessed: 24.01.2019)6.

6 The occupational barometer is a qualitative study. It is created separately for each district in Poland. It is based on the opinion of experts who at the turn of the third and fourth quarter meet and analyze together the situation in individual professions. Participants of the survey (employees of district labour offices, private employment agencies and other institutions oriented on the situation on the local labour market) in the course of the discussion provide answers 
Warehouses have ceased to be seen as cost centers only focusing on the flow of goods, and now take a central place in building a lasting competitive advantage. They also now play a pivotal role in the national economy, as an increasing number of people find employment in the constantly growing number of newly built warehouses. These modern warehouses have modern requirements, which include, among others: quick identification of the location of the stored goods, efficient means of internal transport, the possibility of fast product picking.

\section{Automation of warehouse processes}

Rapid technological development, radically changes the work of each generation, becoming an inseparable part of every aspect of life. Today it is difficult to imagine work without the support of advanced devices or computer systems. One of the industries in which new technology fits perfectly is logistics, especially modern warehouses, where technological progress is having a major impact on the storage processes and management of these facilities.

Warehouse processes are activities that are performed during the flow of freight through the warehouse, starting from the unloading of external transport, through receiving, storing, completing for delivery, to issuing and loading of means of external transport. Certain technical and organizational conditions must be provided in order to carry out the warehouse processes ${ }^{7}$ : the storage space in which the tasks will be performed; the machines and devices with which operations will be done; assigning staff with specific tasks; and inventory and stock inventory systems. Increasing competition forces enterprises to continuously improve their warehouse processes $^{8}$. The approach to processes is now considered one of the most important orientations of the organization and management of modern enterprises, which enforces continuous improvement, and the constant search for opportunities to improve everyday operations ${ }^{9}$. Elimination of errors, increased efficiency, significant reduction of operating costs, continuous availability of the range of goods,

to questions about changing the demand for employees in a given profession (list of assessed occupations is prepared on the basis of "Classification of professions and specialties"), and the relationship between the available labour force and the demand on the labour market.

7 Z. Dudziński, M. Kizyn, Poradnik magazyniera, Polskie Wydawnictwo Ekonomiczne, Warszawa 2000.

8 J.P. Van den Berg, Integral Warehouse Management: The Next Generation in Transparency, Collaboration and Warehouse Management Systems, Management Outlook Publishing, Utrecht 2007, p. 599.

9 R. Brajer-Marczak, Konsekwencje ciq̨głego doskonalenia procesów w organizacjach, [in:] S. Nowosielski, Podejście procesowe w organizacjach, "Prace Naukowe Uniwersytetu Ekonomicznego we Wrocławiu” 2009, no. 52, pp. 153-161. 
improvement of control over processes and increased precision and speed of information flow are some of the benefits of automation in the warehouse.

Interest in warehouse automation among Polish companies is rising, and it is often treated as a way to develop the company through the introduction of modern technological solutions to optimize the entire process of the flow of goods. The most often considered type of warehouse automation projects according to the report of the Panel of Polish Logistics Managers from $2013^{10}$ are: storage zones with AS/RS class devices (automatic storage and unloading of goods: stacks, overhead cranes, forklifts, miniloads), automatic internal transport systems (conveyors, suspended or rail transport systems, shuttle trucks), automatic picking systems (e.g. layer pickers, picking robots), sorters, automatic palletizers, AGV/LGV self-propelled trolleys. Although well-developed western companies have been investing in automation for some time, Polish companies are only now beginning to show interest, and it is currently regarded as a leading trend on the warehouse market.

Automation in its wider sense is also consistent with Poland's development policy priorities. The Ministry of Investment and Development specified National Intelligent Specializations (KIS), according to which funding is allocated within The Intelligent Development Operational Program for 2014-2020. In this document, automation of warehouse processes has been specified in KIS 13. "Electronics Printing, Organic and Flexible", where (in part V) one can read that the way to meet the requirements of modern consumers are "intelligent warehouses with highly automated logistics processes, such as automatic product recognition or autonomous quality control"11. Part I of KIS 12 "Automation and Robotics of The Technological Processes" concerns the design and optimization of the processes, part II process automation and robotics technology, and part $\mathrm{V}$ machines and devices automating and robotizing the processes ${ }^{12}$.

What is extremely important in the modern world automation of warehouse processes is it being consistent with the sustainable development concept. Cost reduction is not the only desired effect of the modernization and optimization of warehouse processes, the reduction of any negative impact on the natural environment is another, also pivotal, one. To sum up, the advantages of automation are primarily space and labor cost savings, availability 24 hours a day, and savings on other operating costs, such as heating and lighting. In addition, automation

10 Report Warehouse automation - practical experience of Polish companies, 4th edition of this study carried out in 2013, developed based on the response of 267 respondents (people responsible for logistics in Polish enterprises).

11 Krajowa Inteligentna Specjalizacja (KIS), Ministerstwo Rozwoju, p. 59, https://smart.gov.pl /images/pdf/Krajowa-inteligentna-specjalizacja_0.pdf (accessed: 4.09.2020).

12 Ididem, p. 61. 
provides the possibility of scalability and flexibility of capacity, which is extremely important in e-commerce environments, where one can find a large variation in demand.

\section{Automation and the future of work in a warehouse}

For hundreds of years there has been the perceived threat that machines will take people's jobs. Even though, historically, developments in technology did not cause long-term unemployment, it only changed the situation on the labour market, making human work easier. In the nineteenth century, Karl Marx argued that the use of machines would deprive people of work ${ }^{13}$. In 1930, John Maynard Keynes postulated a thesis about widespread unemployment resulting from technology ${ }^{14}$. George Friedman in 1950s posed the problem of man and his work in the world of machinery, heralding many threats resulting from this combination ${ }^{15}$. In the mid-1970sMarxist Harry Braverman warned against the degradation of work, which, in his opinion, would be transformed from the use of skills and experience into a mindless, powerless activity, based around machines ${ }^{16}$. Nowadays, among the sceptics of the future of work, Jeremy Rifkin should be mentioned, this controversial American economist, believes that technological progress will mean a reduction in the number of jobs, and the only effective way to provide the unemployed with the benefits resulting from the increased productivity of automation, is to guarantee them a certain income ${ }^{17}$.

According to the World Bank Report The Changing Nature of Work from January 2019, such a distressing scenario that automation is going to exclude the human factor is unjustified. It is undeniable that in developed economies and middle-income countries, jobs most susceptible to replacement are those that perform routine tasks. On the other hand, modern technology creates opportunities for developing new professions ${ }^{18}$. Other research on the impact of artificial intelligence and robots on human work from 2014, proved that the development of technology will

13 See more: K. Marx, Kapitał 1.1. Rezultaty bezpośredniego procesu produkcji, Wydawnictwo Naukowe PWN, Warszawa 2013.

14 See more: J.M. Keynes, Economic Possibilities for Our Grandchildren, [in:] J.M. Keynes, Essays in Persuasion, Harcourt Brace, New York 1963, pp. 321-332.

15 See more: G. Friedmann, Maszyna i człowiek, Książka i Wiedza, Warszawa 1961.

16 See more: H. Braverman, Labour and Monopoly Capital. The Degradation of Work in the Twentieth Century, Monthly Review Press, New York 1974.

17 J. Rifkin, The End of Work: The Decline of the Global Labour Force and the Dawn of the PostMarket Era, Wydawnictwo Dolnośląskie, Wrocław 2001, p. 331.

18 A World Bank Group Flagship Report, World Development Report 2019. The Changing Nature of Work, http://documents.worldbank.org/curated/en/816281518818814423/pdf/2019-WDR -Report.pdf (accessed: 26.10.2019). 
cause a numerical rise of workplaces at a rate close to or faster than their elimination $^{19}$. According to a report by PricewaterhouseCoopers, around $6 \%$ of all professions in the United Kingdom in 2013 did not exist in the 1990 s $^{20}$. What is more, the citizens of the European Union are also optimistic, with 75\% of them believing that jobs can only benefit from new technology 21 .

The link between available employees and the needs of employers for warehousemen (depicted in Figure 2), as well as the very high costs of implementing such autonomous technologies that, allegedly, creates people-less warehouses, confirm the thesis that people cannot be fully replaced by automation and robots in the warehouse. It is also assumed that some human skills, such as: social competences (empathy, argumentation, negotiation); intellectual creativity; IT skills, such as programming and system administration; perceptiveness; ability to move and work in a turbulent environment cannot be automated ${ }^{22}$.

The interaction between people and machines in warehouse work has not been given much attention in the contemporary literature on the subject, even though, despite the fact that warehouse processes are becoming ever more automated, people will still have to work, cooperating with machines. A vision of automation that relieves people from tedious work and allows them to devote themselves to more important professions appeared over 60 years ago, when the world was impressed by the first generation of robots ${ }^{23}$. To achieve this, the relationship between human and machines in the context of modern technology should be analysed. The impact of automation and modern technologies on work are come, primarily, form a study of Frey and Osborne from the Oxford University Engineering Sciences Department: The Future of Employment: How Susceptible Are Jobs to Computerization? conducted in 2013 in the United States. They made an attempt to determine computerization ratios for 702 positions, from the least "computerizable" (recreational therapist) to the most

19 A. Smith, J. Anderson, Al, Robotics, and the Future of Jobs, Pew Research Center, 2014, http:// www.pewinternet.org/2014/08/06/future-of-jobs/ (accessed: 27.10.2019).

20 PricewaterhouseCoopers, Will robots really steal our jobs? An international analysis of the potential long term impact of automation, 2017, https://www.pwc.co.uk/economicservices/assets/international-impact-of-automation-feb-2018.pdf (accessed: 26.10.2019).

21 Special Eurobarometer 460, Attitudes towards the Impact of Digitization and Automation on Daily Life, https://ec.europa.eu/digital-single-market/en/news/attitudes-towards-impa ct-digitisation-and-automation-daily-life (accessed: 27.10.2019).

22 Houses of Parliament, Parliamentary Office of Science \& Technology, Automatic and Workforce, Postnote no. 534, London, August 2016, p. 3, https://post.parliament.uk/research-br iefings/post-pn-0534/ (accessed: 4.09.2020)

23 G. Friedmann, Maszyna..., p. 176. 
(telemarketer) ${ }^{24}$. An empirical assessment of the study by Frey and Osborne on OECD countries was conducted in 2016 by Arntz, Gregory, and Zierahn entitled The Risk of Automation for Jobs in OECD Countries ${ }^{25}$, though changing the research approach a little. According to the authors, the main limitation of the research by Frey and Osborne is that they examined jobs rather than the actual tasks threatened by automation. They postulate that many professions classified as "susceptible to automation" are, in fact, not at risk; the reason is that employees also perform non-routine and interactive tasks that are not that susceptible to automation. Another example of using the methodology of the aforementioned research (conducted between 2013 and 2016) is the analysis conducted by PricewaterhouseCoopers in 2018 under the title: Will robots really steal our jobs? An international analysis of the long-term impact of automation ${ }^{26}$. What differentiates this research is that the predictions made in this research are based on the assumption of the technical possibilities of automation, so, in practice, the actual range of automation could be smaller due to economic, legal, regulatory and organizational reasons. Research on automation and work developed by the McKinsey Global Institute are: A future that works. Automation, Employment and Productivity 27 from January 2017, Jobs lost, jobs gained: Workforce transitions in a time of automation from December 2017, Skill Shift. Automation and the Future of the Workforce from May 2018. Considerations about changes in the nature of work in the context of advanced technologies were also included in the World Bank: The World Development Report (WDR) 2019: The Changing Nature of Work ${ }^{28}$.

Research on warehouse employees regarding their personality traits and motivational factors, was carried out by the scientists from Erasmus University of Rotterdam in 2016, entitled: Exploring the role of picker personality in predicting picking performance with pick by voice, pick to light and RF-terminal picking 29 and

24 C.B. Frey, M.A. Osborne, The Future of Employment, Delloite, 2013, https://www.oxfordmar tin.ox.ac.uk/downloads/academic/The_Future_of_Employment.pdf (accessed: 27.10.2019).

25 M. Arntz, T. Gregory, U. Zierahn, The Risk of Automation for Jobs in OECD Countries: A Comparative Analysis, OECD Social, Employment and Migration Working Papers, No. 189, OECD Publishing, Paris 2016, http://dx.doi.org/10.1787/5jlz9h56dvq7-en (accessed: 27.10.2019).

26 PricewaterhouseCoopers, Will robots really steal our jobs?...

27 McKinsey Global Institute, A Future that works: automation, employment, and productivity. January 2017. Executive summary, https://www.mckinsey.com/ /media/mckinsey/featured \%20insights/Digital\%20Disruption/Harnessing\%20automation\%20for\%20a\%20 future $\% 20$ that $\% 20$ works/MGI-A-future-that-works-Executive-summary.ashx (accessed: 29.10.2019).

28 A World Bank Group Flagship Report, World Development Report 2019...

29 J. De Vries, R. De Koster, D. Stam, Exploring the role of picker personality in predicting picking performance with pick by voice, pick to light and RF-terminal picking, "International Journal 
Aligning order picking methods, incentive systems, and regulatory focus to increase performance ${ }^{30}$, which concern the automated picking process.

\section{Results and Discussion}

The research was carried out using the CAPI method on respondents from warehouse employees from various regions of Poland. The survey enquired about the technical equipment of their warehouses, working conditions and whether warehouse workers feel under threat of losing their jobs in the next 5 years due to the increasing automation of work. The main aim of the survey was the identification of the opinion warehouse workers have regarding the automation of their work. 83 respondents selected by the targeted selection method took part in the survey. The respondents were warehouse employees from all over Poland, occupying a range of positions in the warehouse (Figure 3) and having different professional experience.

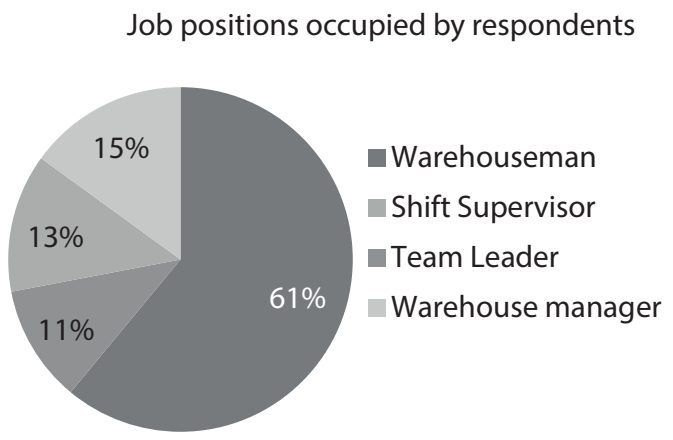

Figure 3. Positions occupied by respondents

Source: own elaboration based on research results.

Most of the respondents were men (75\%). Women constituted a quarter of all respondents (25\%). Both groups of respondents are young, 70\% of respondents are people under 35 years of age (Figure 4) with professional experience not exceeding 15 years.

of Production Research" 2016, vol. 54(8), pp. 2260-2274.

30 J. De Vries, R. De Koster, D. Stam, Aligning order picking methods, incentive systems, and regulatory focus to increase performance, "Production and Operations Management" 2016, vol. 25(8), pp. 1363-1376. 
Age of respondents

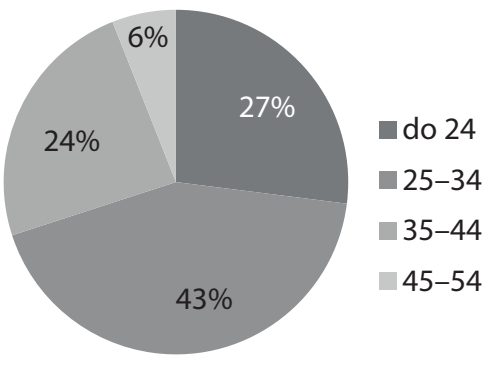

Figure 4. Age of respondents

Source: own elaboration based on research results.

The largest group were employees aged 25-34 (43\%). 44\% of respondents have a relatively limited work experience, up to 5 years, including working in a warehouse for up to 4 years. Regardless of job seniority, age, position, education and gender, all respondents found that the use of ancillary equipment significantly facilitates warehouse work. $3 \%$ of respondents work in warehouses where there are none of the auxiliary devices listed below. Among the auxiliary devices available in their warehouses respondents most often mentioned:

- lifting forklifts $83 \%$;

- pallet truck $81 \%$;

- sliding shelves $36 \%$;

- conveyor belts $33 \%$;

- conveyors $29 \%$;

- mechanical loading bridges $12 \%$;

- stacker cranes $12 \%$;

- warehouse bridge cranes 9\%.

Despite these numerous auxiliary devices, $39 \%$ of warehouse workers, $25 \%$ of warehouse managers and $22 \%$ of team leaders believe that their work is physically exhausting. $27 \%$ of shift managers and $29 \%$ of warehouse staff hold the opposite view - these respondents believe that their work is neither physically nor mentally tiring. In terms of mental tiredness, half of the managers believe that their work is exhausting. The same opinion is expressed by $36 \%$ of shift managers, $44 \%$ of team leaders but only $8 \%$ of warehouse workers. $25 \%$ of managers, $36 \%$ of shift managers, $33 \%$ of team leaders and $27 \%$ of warehouse workers feel both physical and mental exhaustion. To sum up, it can be stated that working in a warehouse exhausts a third of warehouse employees physically, while over a quarter of employees feel that their work exhausts them both physically and mentally. In contrast, $22 \%$ of employees believe that their work in the warehouse is not exhausting. 
Every fifth respondent believes that working in a warehouse exhausts them mentally. Detailed research results are presented in Table 1.

Table 1. Exhaustion of warehouse employees in physical and mental terms

\begin{tabular}{|l|c|c|c|c|c|}
\hline \multicolumn{1}{|c|}{ Exhaustion } & $\begin{array}{c}\text { Warehouse } \\
\text { manager }\end{array}$ & Shift Supervisor & $\begin{array}{c}\text { Team } \\
\text { leaders }\end{array}$ & Warehouseman & All \\
\hline Physical & $25 \%$ & $0 \%$ & $22 \%$ & $39 \%$ & $30 \%$ \\
\hline Mental & $50 \%$ & $36 \%$ & $44 \%$ & $8 \%$ & $22 \%$ \\
\hline Physical and mental & $25 \%$ & $36 \%$ & $33 \%$ & $24 \%$ & $27 \%$ \\
\hline Work is not exhausting & $0 \%$ & $27 \%$ & $0 \%$ & $29 \%$ & $22 \%$ \\
\hline
\end{tabular}

Source: own elaboration based on research results.

The survey also asked respondents whether their warehouse role would be fully automated and whether they were afraid of losing their job due to automation. The respondents' answers depended on their position and, therefore, on the work they performed.

In general, $40 \%$ of respondents believe that their work cannot be fully automated, the same number of responders (40\%) disagreed. 20\% are not determined in this matter. Opinions are also divided on the issue of job loss. 52\% of respondents believe that despite automation they will not lose their jobs, while $48 \%$ express such a fear.

Detailed results for the position held by the respondents are presented in Tables 2 and 3 .

Table 2. Employees' concerns about job loss due to warehouse automation

\begin{tabular}{|c|l|r|r|r|}
\hline \multicolumn{5}{|c|}{ Do you think that your warehouse work could be fully automated? } \\
\hline Job position & \multicolumn{1}{|c|}{ Answer } & $\%$ & I will be out of work & I will have a job \\
\hline \multirow{3}{*}{ Warehouse manager } & Yes & $42 \%$ & $25 \%$ & $75 \%$ \\
\cline { 2 - 5 } & I have no opinion & $0 \%$ & $0 \%$ & $0 \%$ \\
\cline { 2 - 5 } & No & $58 \%$ & $33 \%$ & $67 \%$ \\
\hline \multirow{3}{*}{ Shift Supervisor } & Yes & $55 \%$ & $40 \%$ & $60 \%$ \\
\cline { 2 - 5 } & I have no opinion & $9 \%$ & $100 \%$ & $0 \%$ \\
\cline { 2 - 5 } & No & $36 \%$ & $0 \%$ & $100 \%$ \\
\hline \multirow{3}{*}{ Weam leaders } & Yes & $44 \%$ & $67 \%$ & $33 \%$ \\
\cline { 2 - 5 } & I have no opinion & $12 \%$ & $100 \%$ & $0 \%$ \\
\cline { 2 - 5 } & No & $44 \%$ & $0 \%$ & $300 \%$ \\
\hline & Yes & $35 \%$ & $67 \%$ & $36 \%$ \\
\cline { 2 - 5 } & I have no opinion & $30 \%$ & $64 \%$ & $22 \%$ \\
\cline { 2 - 5 } & No & $35 \%$ & $78 \%$ & \\
\hline
\end{tabular}

Source: own elaboration based on research results. 
The wider the range of devices that facilitate work in the warehouse, the greater the fear of losing a job - $80 \%$ vs. $0 \%$ (Table 3 ).

Table 3. Concerns about job loss due to automation with regard to the number of different technical devices used in a given warehouse that facilitate warehouse work

\begin{tabular}{|c|c|c|c|}
\hline & \multicolumn{2}{|c|}{ Number of different technical devices } \\
\hline & & $0-1$ & $6-8$ \\
\hline \multirow{3}{*}{$\begin{array}{l}\text { My work will } \\
\text { be completely } \\
\text { automated }\end{array}$} & Yes & $55 \%$ & $20 \%$ \\
\hline & I have no opinion & $10 \%$ & $20 \%$ \\
\hline & No & $30 \%$ & $60 \%$ \\
\hline \multirow{3}{*}{$\begin{array}{l}\text { I will lose } \\
\text { my job because } \\
\text { of automation }\end{array}$} & Yes & $0 \%$ & $80 \%$ \\
\hline & I have no opinion & $0 \%$ & $0 \%$ \\
\hline & No & $100 \%$ & $20 \%$ \\
\hline
\end{tabular}

Source: own elaboration based on research results.

The research shows that $58 \%$ of managers strongly believe that their work cannot be automated. For all other groups, 35-44\% of respondents replied that their work would not be fully automated. In these groups participants also answered "I have no opinion". The lower the position held, and therefore the easier tasks to perform, the greater this uncertainty (30\% of warehouse workers versus $9 \%$ of shift managers). Interestingly, both team leaders and shift managers who are not certain whether their work will be replaced by machines are convinced that they will be out of work due to progressing automation. More than half of shift managers (55\%) answered this question in the affirmative. The smallest percentage of positive answers was in the group of warehouse workers (35\%). It is intriguing that the same percentage of team leaders (44\%) and warehousemen (35\%) believe that their work can and cannot be automated. Warehouse personnel have the greatest concerns over job loss among those respondents who believe that their work will not be fully automated (78\%).

It has to be emphasized that the above answers were not influenced by education, gender, age or seniority. However, as mentioned, the answers depended on the position held and the range of machine equipment in the warehouses in which the respondents work. Warehouse employees who have no or only one type of such devices are not worried about losing their jobs due to automation. It can therefore be assumed that the greater the technical equipment in the warehouse, the greater the employees' awareness of human labour being phased out from the warehouse. The summary of the results of the answers to the question about the fear of losing a job in reference to the positions occupied by respondents is also interesting. Overall, 75\% of managers are not afraid of losing their jobs due to automation, while more than half of warehouse workers are (53\%). For shift supervisors 
and team leaders, the percentage of people afraid of losing their jobs is the same (45\%). Respondents were also asked if they would like to change jobs in the next five years. As many as $78 \%$ of team leaders, $74 \%$ of warehouse workers and $67 \%$ of warehouse managers answered this question affirmatively. The respondents provide more varied answers when asked whether they would like to change their profession in the next five years. Warehouse managers and shift managers mostly do not have such intentions (respectively $67 \%$ and $64 \%$ ). Whereas $63 \%$ of warehouse workers and over half of team leaders (56\%) want to change their profession in the near future.

\section{Conclusions}

The research shows that work in the warehouse is not particularly exhausting physically, which is associated with the increasing use of various technical devices that facilitate warehouse work. Employees' opinions as to whether their work can be fully automated are divided. $40 \%$ of them think it is possible, while another $40 \%$ disagree. Every fifth respondent had no opinion on this subject. On the other hand, as the warehouses are equipped with greater numbers of technical devices, employees' fear of losing their jobs increases, although this fear depends not only on the degree of technical infrastructure of the warehouse, but also on the position occupied by a given employee. The higher the position, the more they believe that their work cannot be fully automated and that, despite automation, they will keep their job. None of the employees who work in lowlevel position in warehouses are afraid of losing their jobs. Perhaps employee confidence is related to the economic situation of the company in which they are employed (this aspect has not been studied), one which does not allow the purchase of expensive technical equipment used in large modern, automated warehouses. Employees of almost all surveyed groups (except team leaders) want to change their position in the next five years (over 67\%), although this change is not necessarily related to a change in their profession.

The authors of the article intend to continue their research on the impact of automation on work, accidents in the warehouse and on occupational diseases associated with this work. 
References

Arntz M., Gregory T., Zierahn U., The Risk of Automation for Jobs in OECD Countries: A Comparative Analysis, OECD Social, Employment and Migration Working Papers, No. 189, OECD Publishing, Paris 2016, http://dx.doi.org/10.1787/5jlz9h56dvq7-en (accessed: 27.10.2019).

A World Bank Group Flagship Report, World Development Report 2019. The Changing Nature of Work, http://documents.worldbank.org/curated/en/816281518818814423/pdf/2019 -WDR-Report.pdf (accessed: 26.10.2019).

Barometr zawodów, https://barometrzawodow.pl (accessed: 24.01.2019).

Brajer-Marczak R., Konsekwencje ciągłego doskonalenia procesów w organizacjach, [in:] S. Nowosielski, Podejście procesowe w organizacjach, "Prace Naukowe Uniwersytetu Ekonomicznego we Wroctawiu" 2009, no. 52, pp. 153-161.

Braverman H., Labour and Monopoly Capital. The Degradation of Work in the Twentieth Century, Monthly Review Press, New York 1974.

De Vries J., De Koster R., Stam D., Aligning order picking methods, incentive systems, and regulatory focus to increase performance, "Production and Operations Management" 2016, vol. 25(8), pp. 1363-1376.

De Vries J., De Koster R., Stam D., Exploring the role of picker personality in predicting picking performance with pick by voice, pick to light and RF-terminal picking, "International Journal of Production Research" 2016, vol. 54(8), pp. 2260-2274.

Dobosiewicz J., Padły trzy ważne rekordy na polskim rynku magazynowym, https://businessins ider.com.pl/finanse/rynek-magazynowy-w-polsce-i-polrocze-2018-r/j94f2hx (accessed: 23.10.2019).

Dudziński Z., Kizyn M., Poradnik magazyniera, Polskie Wydawnictwo Ekonomiczne, Warszawa 2000.

Fechner I., Szyszka G., Logistyka w Polce. Raport 2017, Biblioteka Logistyka, Poznań 2018.

Ferstsch M., Stownik terminologii logistycznej, Instytut Logistyki i Magazynowania, Poznań 2016.

Frey C.B., Osborne M.A, The Future of Employment, Delloite, 2013, https://www.oxfordmartin .ox.ac.uk/downloads/academic/The_Future_of_Employment.pdf (accessed: 27.10.2019).

Friedmann G., Maszyna i człowiek, Książka i Wiedza, Warszawa 1961.

Houses of Parliament, Parliamentary Office of Science \& Technology, Automatic and Workforce, Postnote no. 534, London, August 2016, https://post.parliament.uk/research-briefings/po st-pn-0534/ (accessed: 4.09.2020).

JLL, Rynek magazynowy w Polsce lipiec 2020, https://www.jll.pl/pl/trendy-i-analizy/badanie/ry nek-magazynowy-w-polsce (accessed: 27.10.2019).

Keynes J.M., Economic Possibilities for Our Grandchildren, [in:] J.M. Keynes, Essays in Persuasion, Harcourt Brace, New York 1963, pp. 321-332.

Kisperska-Moroń D., Krzyżaniak S., Logistyka, Biblioteka Logistyka, Poznań 2009.

Krajowa Inteligentna Specjalizacja (KIS), Ministerstwo Rozwoju, https://smart.gov.pl/images/pdf /Krajowa-inteligentna-specjalizacja_0.pdf (accessed: 4.09.2020).

Marx K., Kapitał 1.1. Rezultaty bezpośredniego procesu produkcji, Wydawnictwo Naukowe PWN, Warszawa 2013.

McKinsey Global Institute, A Future that works: automation, employment, and productivity. January 2017. Executive summary, https://www.mckinsey.com/ /media/mckinsey/featured\%20 insights/Digital\%20Disruption/Harnessing\%20automation\%20for\%20a\%20future\%20th at\%20works/MGI-A-future-that-works-Executive-summary.ashx (accessed: 29.10.2019).

PricewaterhouseCoopers, Will robots really steal our jobs? An international analysis of the potential long term impact of automation, 2017, https://www.pwc.co.uk/economic-services/asse ts/international-impact-of-automation-feb-2018.pdf (accessed: 26.10.2019). 
Rifkin J., The End of Work: The Decline of the Global Labour Force and the Dawn of the Post-Market Era, Wydawnictwo Dolnośląskie, Wrocław 2001.

Smith A., Anderson J., Al, Robotics, and the Future of Jobs, Pew Research Center, 2014, http:// www.pewinternet.org/2014/08/06/future-of-jobs (accessed: 27.10.2019).

Special Eurobarometer 460, Attitudes towards the Impact of Digitization and Automation on Daily Life, https://ec.europa.eu/digital-single-market/en/news/attitudes-towards-impact-digiti sation-and-automation-daily-life (accessed: 27.10.2019).

Van den Berg J.P., Integral Warehouse Management: The Next Generation in Transparency, Collaboration and Warehouse Management Systems, Management Outlook Publishing, Utrecht 2007.

\section{Abstract}

Contemporary enterprises operate in conditions of high uncertainty, where competition takes place not only at the level of prices of products or services offered, but above all on quality. The time taken to deliver a product or service is one of the most important quality measures. The role and importance of the logistics system in the current competitive environment is of fundamental importance. Warehouses have ceased to be perceived as cost centers, just being a central place in the flow of goods, and are gaining ever more importance in building a lasting competitive advantage. There are also growing requirements for modern warehouses (identification of the place where the goods are stored, efficient means of internal transport, the possibility of quick product picking). Technological progress and automation has a huge impact on the way warehouse processes are carried out and managed. And this technology is developing extremely quickly, radically changing work in the warehouse. Elimination of errors, increased efficiency, significant reduction of operating costs, assurance of constant availability of the full range of goods, the improvement of process control, increase of precision and speed of information flow are some of the benefits of introducing automation in the warehouse. Although warehouse processes are becoming increasingly automated, people will still have to a role by collaborating and interacting with machines. Due to the fact that the interaction between man and machine in warehouse work has not been the subject of much attention in contemporary literature on the subject, the purpose of the article is to assess the impact of automation on warehouse work, through CAPI research directed at warehouse employees. What impact the current technology has on people's work was assessed, whether large fluctuations and staff shortages among warehouse workers are not a repercussion of treating them as supplementary to modern machines, or whether they feel at risk of losing their jobs due to automation.

Keywords: automated warehousing, automated storage, warehouseman, logistics, humanautomation interaction 